\title{
EFFECTS OF IRRIGATION FREQUENCY AND LEVEL ON YIELD AND STOMATAL RESISTANCE OF EGGPLANT (SOLANUM MELONGENA L.) GROWN IN OPEN FIELD IRRIGATED WITH SURFACE AND SUBSURFACE DRIP METHODS
}

\author{
BOZKURT ÇOLAK, Y. \\ Soil and Water Resources Research Unit, Alata Horticultural Research Institute \\ 33400 Mersin, Turkey \\ (e-mail: yesimcolak@ymail.com; phone: +90-324-644-6478)
}

(Received 6 ${ }^{\text {th }}$ Aug 2019; accepted $15^{\text {th }}$ Nov 2019)

\begin{abstract}
A two-year field experiment was conducted to evaluate the physiological response of eggplant stomatal resistance $\left(\mathrm{r}_{\mathrm{s}}\right)$ and yield to different deficit irrigation levels using surface and subsurface drip methods under Mediterranean climatic conditions. Treatments consisted of surface (SDI) and subsurface drip (SSDI); 3-day and 6-day irrigation frequencies $\left(\mathrm{IF}_{3}, \mathrm{IF}_{6}\right)$; and full irrigation $(\mathrm{FI})$, deficit irrigations $\left(\mathrm{DI}_{50}, \mathrm{DI}_{75}\right)$ and partial root-zone drying $\left(\mathrm{PRD}_{50}\right)$. Irrigation systems, frequencies and levels produced significantly different eggplant yields. $\mathrm{IF}_{3} \mathrm{FI}$ treatment produced the greatest yield in the experimental years and followed by $\mathrm{IF}_{3} \mathrm{DI}_{75}$. The results revealed that 3-day interval resulted in significantly greater yields than 6-day frequency. Water deficit in the root-zone decreased fresh eggplant yield drastically and $\mathrm{IF}_{6} \mathrm{PRD}_{50}$ produced the lowest yield. Smaller $r_{s}$ values were observed in FI treatment in SDI and SSDI systems under 3-day frequency than deficit irrigated and 6-day frequency plots. Significant relationships among $\mathrm{r}_{\mathrm{s}}$ and yield, dry matter yield, SWC, ET, and LAI were obtained. A value of $60 \mathrm{~s} \mathrm{~m}^{-1}$ could be considered as the threshold to regulate rs for high eggplant yield. Therefore rs could be utilized for scheduling irrigations. The $\mathrm{r}_{\mathrm{s}}$ response to water stress can be used for sustainable crop production in water scarce regions.

Keywords: deficit irrigation, partial root-zone drying, water use efficiency, irrigation scheduling
\end{abstract}

\section{Introduction}

Vegetable production in many countries relies on irrigation. Optimizing irrigation amount and frequency is thus essential to ensure yield increase without compromising quality. All over the world, the reduction in the amount of water which is used for irrigation and environmental concerns make obtaining the most benefit from a unit of water necessary. Therefore micro irrigation systems such as surface drip (SDI) and subsurface drip systems (SSDI) are necessary for efficient use of scarce water resources in irrigated agriculture for increasing yield and saving water. A number of field studies indicated relevant benefits of managing SSDI for production of vegetables (Lamm and Camp, 2007; Kong et al., 2012; Bozkurt and Sayilikan Mansuroğlu, 2018).

Deficit irrigation (DI) is an important water-saving practice in irrigated agriculture (English et al., 2002). DI could decrease vegetative growth, while having little effect on fruit growth and development through balancing the relationship between reproductive and vegetative growth (Goodwin and Boland, 2002). Moreover, DI significantly reduces irrigation amount (Pérez-Pérez et al., 2008).

Several field trials on eggplant irrigation have been conducted in various locations around the world (Chartzoulakis and Drosos, 1995; Gaveh et al., 2011; Diaz-Perez and Eaton, 2015; Mohawesh, 2016; Müller et al., 2016; Bozkurt Çolak et al., 2017) indicating that eggplant production can be realized at moderate water stress levels without major reduction in crop yield. 
Irrigation scheduling methods is usually categorized on soil, plant, and meteorological basis. Plant-based irrigation scheduling techniques are more advantageous since plants respond to both the soil and aerial environmental conditions (Yazar et al., 1999). For that reason, crop based irrigation scheduling is used more and more in recent years. The irrigation time can be determined by detecting the water stress status of the plant. Among the possible measures of some aspect of plant water status include direct measuring stomatal resistance or conductance (Yao et al., 2001; Agele et al., 2006; Lianga et al., 2011) that is known to respond sensitively to water stress.

Stomatal have an important task in regulating water losses through transpiration and $\mathrm{CO}_{2}$ uptake for photosynthesis and plant growth (Gerosa et al., 2012). Also, stomatal control is a major physiological way for optimizing water use under drought condition (Makbul et al., 2011). Crop water use estimation based on scaling up from leaf stomatal conductance to canopy conductance is of paramount importance for improving efficient use of limited water resources in agriculture (Zhang et al., 2011).

It is believed that virtually most of the plants' first reaction to severe water stress is the stomatal closure to prevent the water losses by transpiration (Berry et al., 2010; Brodribb and McAdam, 2011; Nemeskeri et al., 2015). Stomatal closure occurs due to from direct evaporation of water from the guard cells without any metabolic action. When available soil water content is decreased, the stomata open little or even remain closed in response to severity of water deficiency. The crop prevents dehydration by maintaining stomata closed under drought conditions (Anjum et al., 2011; Osakabe et al., 2014; Clauw et al., 2015). Behboudian (1977) reported that eggplants have greater resistance to water stress than the other vegetable crops.

For sustainable eggplant production and making decision on the best irrigation practice, a comprehensive assessment of the yield and physiological response of the crop to a specific soil type, production method and irrigation strategy is required. Therefore, determination of the critical threshold values (beyond which yield loss or reduction is inevitable) of stomatal resistance $\left(\mathrm{r}_{\mathrm{s}}\right)$ is important for a specific crop growing under different climatic and soil conditions so that they can be utilized effectively for irrigation scheduling purposes. The main objectives of this research were to evaluate the physiological response of eggplant such as stomatal resistance $\left(r_{s}\right)$ to different deficit irrigation strategies under subsurface and surface drip systems; and to establish threshold levels for stomatal resistance for irrigation scheduling of eggplant for high and good quality yield under the semi-arid climatic environment in the Mediterranean region.

\section{Materials and methods}

\section{Experimental site description}

Field experiments were conducted during 2013 and 2014 growing seasons on the experimental farm at the Alata Horticultural Research Institute in Tarsus in Mediterranean region of Turkey. The experimental site is located between latitude $36^{\circ} 53^{\prime} \mathrm{N}$ and longitude $34^{\circ} 57^{\prime} \mathrm{E}$ with an elevation of $60 \mathrm{~m}$. Mediterranean climate prevails in the experimental site. Monthly mean climatic data for the study years along with long-term means are depicted in Figure 1. The mean annual rainfall, temperature, evaporation and relative humidity are $616 \mathrm{~mm}, 17.8^{\circ} \mathrm{C}, 1487 \mathrm{~mm}, 70.5 \%$, respectively. The amount of rainfall recorded during the eggplant growing season (May through August) was $163.0 \mathrm{~mm}$ in 2013, and $126.0 \mathrm{~mm}$ in the 2014 growing season. 
The experimental soil has a clayey-silt texture with volumetric water content at field capacity $29.6 \%$ and wilting point $19.2 \%$ and mean bulk density of $1.39 \mathrm{~g} \mathrm{~cm}^{-3}$. Plant available water in the effective root depth of $60.0 \mathrm{~cm}$ was estimated as $88 \mathrm{~mm}$.

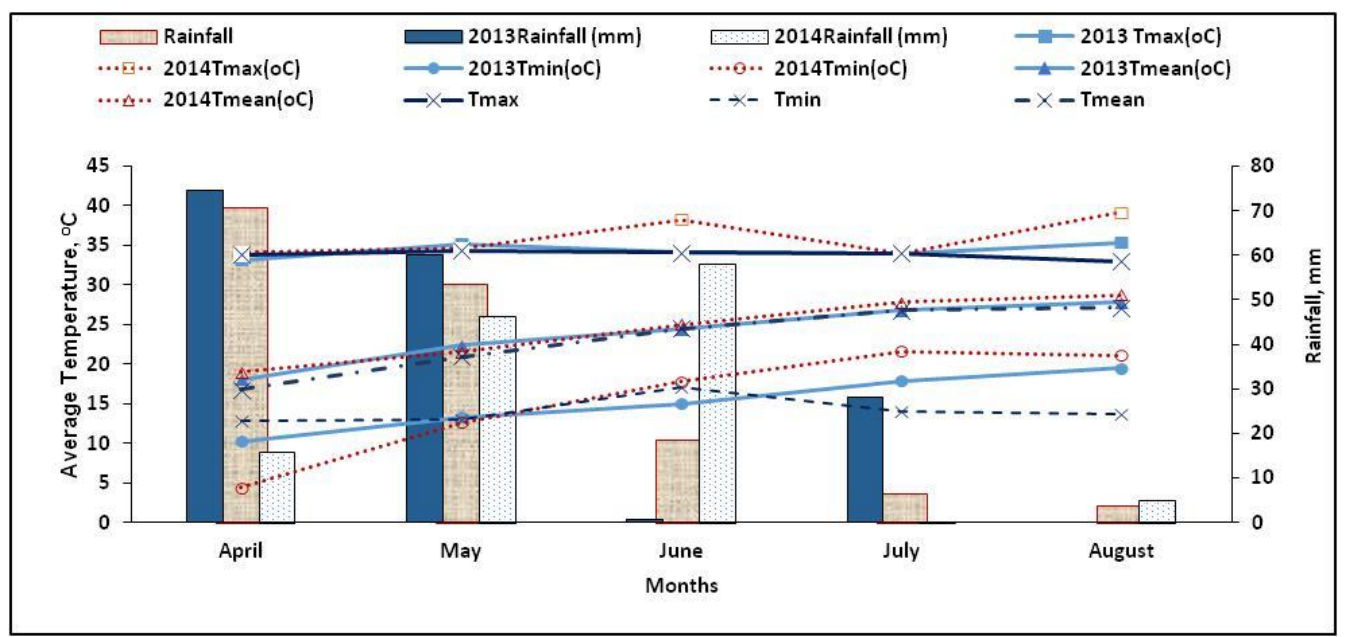

Figure 1. Mean monthly climatic data in the experimental years along with long-term means

\section{Agronomic practices}

Four weeks old eggplant seedlings of Solanum Melongena L. (cv. Anamur Karas1) were transplanted into the experimental plots in $90 \mathrm{~cm}$ row spacing and with $70 \mathrm{~cm}$ plant spacing on May 6 and April 14 in 2013 and 2014, respectively.

Compound fertilizers were incorporated into the plant beds at a rate of $50 \mathrm{~N} ; 50 \mathrm{P}_{2} \mathrm{O}_{5}$; and $50 \mathrm{~kg} \mathrm{ha}^{-1} \mathrm{~K}_{2} \mathrm{O}$ prior to transplanting. About 21 days after transplantation, plots received Nitrogen via fertigation every 6 days $\left(160.0 \mathrm{~kg} \mathrm{ha}^{-1} \mathrm{~N}\right)$ during the eggplant growth period.

Agronomic and plant protection practices carried out during the growing seasons are summarized in Table 1.

\section{Design of the experiment and treatments}

The experiment was designed split-split plots with four replicates. Experimental treatments consisted of surface drip (SDI) and subsurface drip systems (SSDI); 3-day 6-day $\left(\mathrm{IF}_{3} ; \mathrm{IF}_{6}\right)$ irrigation frequencies; and Full irrigation (FI); deficit irrigations, $\mathrm{DI}_{50}$ and $\mathrm{DI}_{75}$; and Partial Root-zone drying (PRD $\left.{ }_{50}\right)$. Irrigation was launched when $25 \%$ of available water in the root-zone depth of $60 \mathrm{~cm}$ was depleted and replenished to field capacity in all treatments. Then treatment irrigations were scheduled based on replenishment of soil water deficit in effective root-zone depth of $60 \mathrm{~cm}$ to field capacity in fully irrigated treatments (FI) in the two irrigation frequencies considered. In the deficit irrigation plots of $\mathrm{DI}_{50}$ and $\mathrm{DI}_{75}$, respectively received 50 and $75 \%$ of water applied to full irrigation plots. $\mathrm{PRD}_{50}$ plots were irrigated alternately from the two laterals on both side of the crop row and received 50\% of water applied to full irrigation plots. In the experiment, subplots were $10 \mathrm{~m}$ long and $5.4 \mathrm{~m}$ (6 plant rows) wide. A general view of the experimental plots is shown in Figure 2.

In the surface drip system plots (SDI), drip lateral pipes were placed in every plant row for $\mathrm{FI}$ and $\mathrm{DI}_{50}$, and $\mathrm{DI}_{75}$ treatments. Drip tapes had inline emitters with discharge 
rate of $1.6 \mathrm{l} \mathrm{h}^{-1}$ spaced at $0.20 \mathrm{~m}$. In the $\mathrm{PRD}_{50}$ treatment, two drip laterals were laid on each side of the plant row $25 \mathrm{~cm}$ away from the eggplant rows. In the subsurface drip irrigation plots (SSDI), laterals were buried at $25 \mathrm{~cm}$ depth in the soil under the plant rows. Lateral with in-line emitters spaced at $0.20 \mathrm{~m}$ intervals and with flow rate of $2.31 \mathrm{~h}^{-1}$ were used (Geoflow Corte Madera, CA, USA). Since the same flow rate and emitter interval surface and subsurface drip systems were not available in the local market, we used the abovementioned systems in the study. The irrigation amount in each plot was measured by a flow meter.

Table 1. Some agronomic and management practices carried out during the experiments in 2013 and 2014

\begin{tabular}{|c|c|c|}
\hline $\begin{array}{l}\text { Agronomic } \\
\text { Practices }\end{array}$ & 2013 & 2014 \\
\hline $\begin{array}{l}\text { Transplanting } \\
\text { date }\end{array}$ & May 6 & April 14 \\
\hline Cultivar & Anamur Karası & Anamur Karası \\
\hline Planting spacing & $90 \mathrm{~cm} \mathrm{x70} \mathrm{cm}$ & $90 \mathrm{~cm} \mathrm{x70} \mathrm{cm}$ \\
\hline Plant density & 155556 plants ha ${ }^{-1}$ & 155556 plants ha ${ }^{-1}$ \\
\hline Fertilization & $\begin{array}{c}50 \mathrm{~N} ; 50 \mathrm{P}_{2} \mathrm{O}_{5} \text {; and } 50 \mathrm{~kg} \mathrm{ha}^{-1} \mathrm{~K} \text { compound } \\
\text { fertilizer at transplanting plots stated to receive } \\
\mathrm{N} \text { through fertigation at every 6-day irrigation } \\
\text { interval }\left(160 \mathrm{~kg} \mathrm{ha}^{-1} \mathrm{~N}\right) \text { three weeks after } \\
\text { transplanting }\end{array}$ & $\begin{array}{c}50 \mathrm{~N} ; 50 \mathrm{P}_{2} \mathrm{O}_{5} ; \text { and } 50 \mathrm{~kg} \mathrm{ha}^{-1} \mathrm{~K} \text { compound } \\
\text { fertilizer at transplanting plots stated to receive } \mathrm{N} \\
\text { through fertigation at every 6-day irrigation } \\
\text { interval }\left(160 \mathrm{~kg} \mathrm{ha}^{-1} \mathrm{~N}\right) \text { three weeks after } \\
\text { transplanting }\end{array}$ \\
\hline Irrigation system & $\begin{array}{c}\text { Inline surface and inline subsurface drip } \\
\text { irrigation }\end{array}$ & Inline surface and inline subsurface drip irrigation \\
\hline $\begin{array}{c}\text { Effective } \\
\text { cultivated area }\end{array}$ & 3456 (80 m lenght x 43.2 m width) & 3456 (80m lenght $x 43.2 \mathrm{~m}$ width) \\
\hline First picking & June 27 & June 16 \\
\hline $\begin{array}{l}\text { Hoeing and } \\
\text { weeding }\end{array}$ & 23 May, 10, 17 June; 2 July & 22 and 29 May, 17 June and 1 July \\
\hline Plant Protection & $\begin{array}{c}\text { On 20.06.2013, insecticide applied against green } \\
\text { worms, leaf galleria fly, red spider, white fly } \\
\text { various insecticides and on } 01.08 .2013 \text { fungicide } \\
\text { against Fusarium oxysporum fungus was } \\
\text { sprayed. }\end{array}$ & $\begin{array}{c}\text { Various insecticides against green worms, aphids, } \\
\text { leaf galleria fly, red spider, white fly on } 25 \text { April, } \\
7 \text { May, } 14 \text { May and } 23 \text { May; On } 25 \text { April, } 14 \text { May } \\
\text { and } 23 \text { May, fungicide was applied against lead } \\
\text { mold and powdery mildew and Fusarium } \\
\text { oxysporum. }\end{array}$ \\
\hline First picking & & June 16 \\
\hline Last picking & Agust 5 & July 25 \\
\hline
\end{tabular}

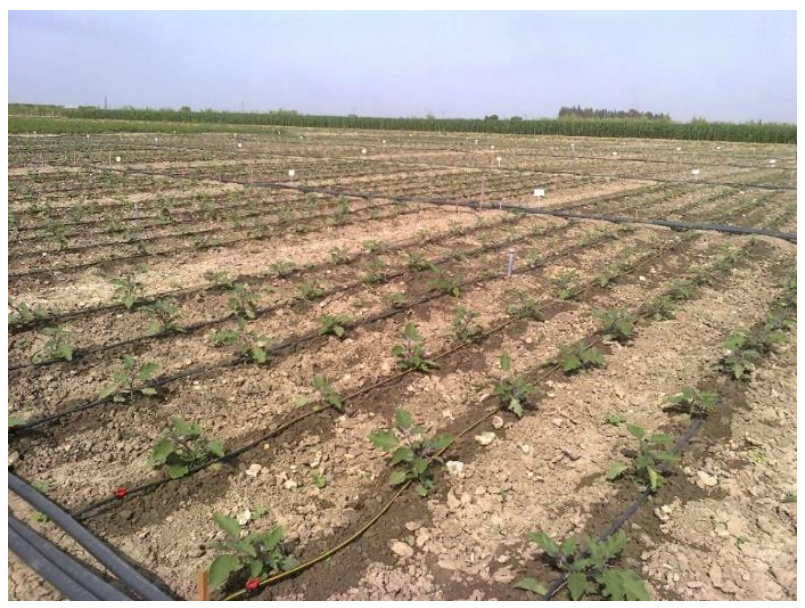

Figure 2. A general view of the experimental plots 


\section{Measurements}

\section{Soil water content}

A neutron moisture meter was used to measure the soil water content (SWC) with (Model $503 \mathrm{DR}$, Martinez, CA) at $0.2 \mathrm{~m}$ depth intervals down to $0.80 \mathrm{~m}$ prior to irrigation applications with 3- and 6-day frequencies during the eggplant growing seasons. Access tubes were placed in the mid plant rows between two plants in the experimental subplots. Average of four replications was taken as mean soil water content for each depth to reduce spatial variability. Gravimetrical sampling method was used to measure SWC in the upper soil layer of $20 \mathrm{~cm}$ during the growing seasons.

\section{Eggplant evapotranspiration and water use efficiency}

Seasonal evapotranspiration (ET) or crop water use was estimated using the water budget equation $E q$. (1).

$$
E T=R+I \mp \Delta W-D p-R o f f
$$

In this equation, ET is seasonal crop water use or evapotranspiration $(\mathrm{mm}), \mathrm{R}$ is rainfall $(\mathrm{mm})$, I is seasonal total irrigation water applied $(\mathrm{mm}), \Delta \mathrm{W}$ is change in soil water storage in the root zone depth $(\mathrm{mm}), \mathrm{Dp}$ is downward soil water movement or deep percolation below the root-zone depth $(\mathrm{mm})$, and Roff is surface runoff $(\mathrm{mm})$. Dp and Roff were neglected since the amount of irrigation water applied via drip systems was precisely controlled and rainfalls received during the growing season was less than soil storage capacity in $60 \mathrm{~cm}$ profile depth.

Water use efficiency (WUE) values were estimated as the ratio of fresh eggplant yield over seasonal crop water use or evapotranspiration (Gong et al., 2017).

\section{Leaf area index}

Leaf areas for experimental treatment plots were estimated using LAI-2000 Plant Canopy Analyzer equipment (Li-Cor 2000, Lincoln, NE) at weekly interval throughout the growing season. In this method of LAI measurement, four measurements below the plant canopy and one measurement above the canopy were taken for each treatment plots to account for the canopy light interception in crop canopy at five different angles, from which LAI was estimated employing radiative transfer model.

\section{Dry matter yield}

Variation of dry matter yields with time in each experimental sub-plot was determined at two-week intervals until harvest by cutting the plants in $2.10 \mathrm{~m}$ of a row section in each subplot at the ground level. The plant samples taken were dried in an oven at $65^{\circ} \mathrm{C}$ for several days until constant dry weight reached.

\section{Stomatal resistance}

A diffusion porometer (AP4 Leaf Porometer, Delta-T Devices, Cambridge, England) was used to determine the stomatal resistance of eggplant leaves (Figure 3).

Measurements were taken at 6-day intervals prior to irrigations until harvest between 12:00 and 14:00 O'clock on the fully developed upper two leaves and under clear sky conditions. Soil water contents were also measured on the same day with porometer 
readings. The porometer was calibrated before making each reading. Using the calibration values, the lower and upper surface resistances of the leaf were calculated with the Equation 2 given by Clawson and Blad (1982).

$$
r_{S}=\frac{r_{u}+r_{l}}{r_{u} \cdot r_{l}}
$$

where $r_{s}$ is the average stomatal resistance $\mathrm{s} \mathrm{m}^{-1} ; \mathrm{r}_{\mathrm{u}}$ and $\mathrm{r}_{l}$ are stomatal resistance of the upper and the lower surface of the leaf, respectively.

Diurnal variations of stomatal resistance were also measured in mid-growth stage once each year before an irrigation application.

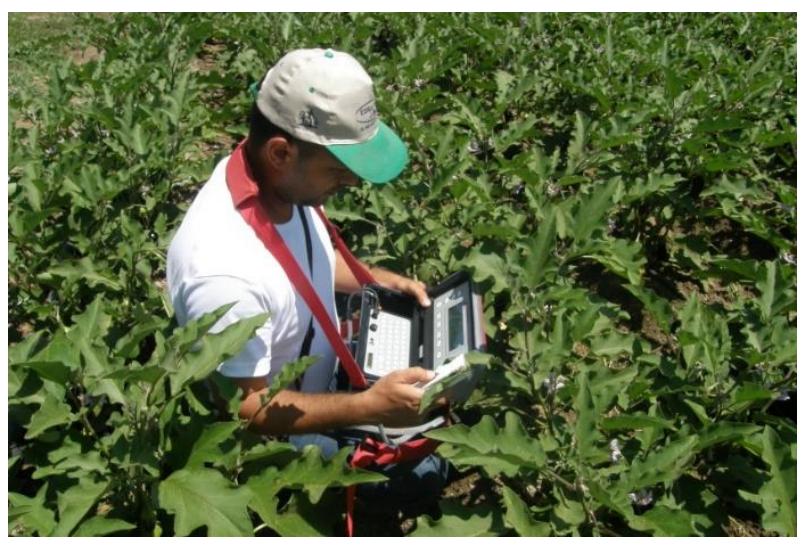

Figure 3. Measurement of stomatal resitance in eggplant with porometer

\section{Statistical analysis}

Statistical analysis of the data was carried out using the JMP Statistical software (SAS Institute, Inc., Cary, NC, USA). Two-way variance analyses (ANOVA) were conducted, and to determine the differences among treatment means Least Significant Difference (LSD) at a 5\% probability level was made (Steel and Torrie, 1980).

\section{Results}

\section{Irrigation and crop water use results}

The data on total irrigation water applied, seasonal evapotranspiration, yield and water use efficiency for the treatments in the experimental years were presented in Table 2. Seasonal irrigation amounts differed between the treatment plots in the growing seasons due to prevailing weather conditions and distribution and quantity of rainfall received during each season. The rainfall received during the growing season in the experimental years was 163 and $126 \mathrm{~mm}$, respectively, which wre greater than long-term mean of $86 \mathrm{~mm}$. Mean maximum temperatures in 2014 in June was $38.2^{\circ} \mathrm{C}$ was higher than 2013 and long-term mean. Mean minimum temperatures in June through August in 2014 were greater than those in 2013 and long-term mean. The data revealed that the seasonal irrigation amount varied between $243 \mathrm{~mm}$ in $\mathrm{IF}_{6} \mathrm{DI}_{50}$ and $\mathrm{IF}_{6} \mathrm{PRD}_{50}$ and $495 \mathrm{~mm}$ in $\mathrm{IF}_{3} \mathrm{FI}$ plots in the SDI plots, and ranged from $228 \mathrm{~mm} \mathrm{IF}_{6} \mathrm{DI}_{50}$ and $\mathrm{IF}_{6} \mathrm{PRD}_{50}$ to $450 \mathrm{~mm}$ in $\mathrm{IF}_{3} \mathrm{FI}$ 
plots the SSDI in 2013 (Table 2). The total irrigation water changed between $229 \mathrm{~mm}$ in $\mathrm{IF}_{6} \mathrm{DI}_{50}$ and $\mathrm{IF}_{6} \mathrm{PRD}_{50}$ to $444 \mathrm{~mm}$ in $\mathrm{IF}_{3} \mathrm{FI}$ in SDI plots; and varied from $216 \mathrm{~mm} \mathrm{IF}_{6} \mathrm{DI}_{50}$ and $\mathrm{IF}_{6} \mathrm{PRD}_{50}$ to $418 \mathrm{~mm}$ in $\mathrm{IF}_{3} \mathrm{FI}$ in the SSDI treatment plots in 2014. PRD 50 and $\mathrm{DI}_{50}$ plots received the same quantity of irrigation water.

Table 2. Eggplant yield, seasonal irrigation, ET, WUE and LAI values under the different treatments in the experimental years

\begin{tabular}{|c|c|c|c|c|c|c|c|}
\hline Years & $\begin{array}{c}\text { Irrigation } \\
\text { systems }\end{array}$ & Treatments & \begin{tabular}{|c|}
$\begin{array}{c}\text { Seasonal irrigation } \\
\mathrm{mm}\end{array}$ \\
\end{tabular} & $\begin{array}{c}\text { ET } \\
\mathbf{m m}\end{array}$ & $\begin{array}{l}\text { Yield } \\
\text { t ha }^{-1}\end{array}$ & $\begin{array}{c}\text { WUE } \\
\mathrm{kg} \mathrm{m}^{-3}\end{array}$ & LAI \\
\hline \multirow{16}{*}{2013} & \multirow{4}{*}{$\begin{array}{l}\text { Surface Drip } \\
\text { (SDI) }\end{array}$} & $\mathrm{IF}_{3} \mathrm{FI}$ & 495 & 543 & 78.7 & $14.5 \mathrm{~h}^{*}$ & 4.13 \\
\hline & & $\mathrm{IF}_{3} \mathrm{DI}_{75}$ & 382 & 441 & 75.3 & $17.1 \mathrm{def}$ & 3.8 \\
\hline & & $\mathrm{IF}_{3} \mathrm{DI}_{50}$ & 268 & 339 & 70.4 & $20.8 \mathrm{~b}$ & 3.47 \\
\hline & & $\mathrm{IF}_{3} \mathrm{PRD}_{50}$ & 268 & 346 & 58.1 & $16.8 \mathrm{f}$ & 2.95 \\
\hline & \multirow{4}{*}{ SDI } & $\mathrm{IF}_{6} \mathrm{FI}$ & 446 & 517 & 69.8 & 13.51 & 3.56 \\
\hline & & $\mathrm{IF}_{6} \mathrm{DI}_{75}$ & 344 & 425 & 63.4 & $14.9 \mathrm{~g}$ & 3.2 \\
\hline & & $\mathrm{IF}_{6} \mathrm{DI}_{50}$ & 243 & 349 & 60.8 & $17.4 \mathrm{~d}$ & 3.07 \\
\hline & & $\mathrm{IF}_{6} \mathrm{PRD} 50$ & 243 & 356 & 48.7 & 13.71 & 2.65 \\
\hline & \multirow{4}{*}{$\begin{array}{l}\text { Subsurface Drip } \\
\quad \text { (SSDI) }\end{array}$} & $\mathrm{IF}_{3} \mathrm{FI}$ & 450 & 495 & 71.9 & $14.5 \mathrm{~h}$ & 4.02 \\
\hline & & $\mathrm{IF}_{3} \mathrm{DI}_{75}$ & 348 & 403 & 69.3 & $17.2 \mathrm{de}$ & 3.73 \\
\hline & & $\mathrm{IF}_{3} \mathrm{DI}_{50}$ & 245 & 306 & 66.9 & $21.9 \mathrm{a}$ & 3.25 \\
\hline & & $\mathrm{IF}_{3} \mathrm{PRD}_{50}$ & 245 & 318 & 53.9 & 17.0 ef & 2.75 \\
\hline & \multirow{4}{*}{ SSDI } & $\mathrm{IF}_{6} \mathrm{FI}$ & 414 & 479 & 60.7 & $12.7 \mathrm{j}$ & 3.45 \\
\hline & & $\mathrm{IF}_{6} \mathrm{DI}_{75}$ & 321 & 398 & 58.1 & $14.6 \mathrm{gh}$ & 3.15 \\
\hline & & $\mathrm{IF}_{6} \mathrm{DI}_{50}$ & 228 & 317 & 56.8 & $17.9 \mathrm{c}$ & 2.91 \\
\hline & & $\mathrm{IF}_{6} \mathrm{PRD}_{50}$ & 228 & 335 & 40.9 & $12.2 \mathrm{k}$ & 2.6 \\
\hline \multirow{16}{*}{2014} & \multirow{4}{*}{$\begin{array}{l}\text { Surface Drip } \\
\quad(\text { SDI })\end{array}$} & $\mathrm{IF}_{3} \mathrm{FI}$ & 444 & 527 & 92.2 & $17.5 \mathrm{~g}$ & 4.30 \\
\hline & & $\mathrm{IF}_{3} \mathrm{DI}_{75}$ & 349 & 441 & 87.6 & $19.9 \mathrm{de}$ & 3.85 \\
\hline & & $\mathrm{IF}_{3} \mathrm{DI}_{50}$ & 253 & 367 & 83.0 & $22.6 \mathrm{~b}$ & 3.55 \\
\hline & & $\mathrm{IF}_{3} \mathrm{PRD}_{50}$ & 253 & 375 & 68.3 & $18.2 \mathrm{f}$ & 3.03 \\
\hline & \multirow{4}{*}{ SDI } & $\mathrm{IF}_{6} \mathrm{FI}$ & 396 & 508 & 87.7 & $17.3 \mathrm{~g}$ & 3.99 \\
\hline & & $\mathrm{IF}_{6} \mathrm{DI}_{75}$ & 312 & 433 & 84.6 & $19.5 \mathrm{e}$ & 3.65 \\
\hline & & $\mathrm{IF}_{6} \mathrm{DI}_{50}$ & 229 & 363 & 77.2 & $21.3 \mathrm{c}$ & 3.30 \\
\hline & & $\mathrm{IF}_{6} \mathrm{PRD}_{50}$ & 229 & 369 & 64.3 & $17.4 \mathrm{~g}$ & 2.80 \\
\hline & \multirow{4}{*}{$\begin{array}{l}\text { Subsurface Drip } \\
\quad \text { (SSDI) }\end{array}$} & $\mathrm{IF}_{3} \mathrm{FI}$ & 418 & 494 & 92.7 & $18.8 \mathrm{f}$ & 4.18 \\
\hline & & $\mathrm{IF}_{3} \mathrm{DI}_{75}$ & 329 & 419 & 88.6 & $21.2 \mathrm{c}$ & 3.79 \\
\hline & & $\mathrm{IF}_{3} \mathrm{DI}_{50}$ & 240 & 350 & 85.7 & $24.5 \mathrm{a}$ & 3.34 \\
\hline & & $\mathrm{IF}_{3} \mathrm{PRD}_{50}$ & 240 & 353 & 68.9 & $19.5 \mathrm{e}$ & 2.97 \\
\hline & \multirow{4}{*}{ SSDI } & $\mathrm{IF}_{6} \mathrm{FI}$ & 369 & 473 & 86.2 & $18.2 \mathrm{f}$ & 3.95 \\
\hline & & $\mathrm{IF}_{6} \mathrm{DI}_{75}$ & 292 & 411 & 83.4 & $20.3 \mathrm{~d}$ & 3.47 \\
\hline & & $\mathrm{IF}_{6} \mathrm{DI}_{50}$ & 216 & 349 & 75.5 & $21.7 \mathrm{c}$ & 3.10 \\
\hline & & $\mathrm{IF}_{6} \mathrm{PRD}_{50}$ & 216 & 354 & 58.8 & $16.6 \mathrm{~h}$ & 2.64 \\
\hline
\end{tabular}

* LSD grouping at $5 \%$ level; each year was analyzed separately

Soil water content variation in different treatments with time in the experimental years are characterized by a gradual decrease in SWC in response to deficit irrigated treatments towards the end of the season as compared with full irrigation plots. In the two drip systems with 3-day frequency plots, plant available water in $\mathrm{FI}$ and $\mathrm{DI}_{75}$ treatments were greater than $50 \%$ during the growing seasons. On the other hand, in $\mathrm{DI}_{50}$ and $\mathrm{PRD}_{50}$ treatments SWC values were below the $50 \%$ available soil water level (soil water data not presented). The detailed information on soil water content variations in the experimental treatments and years can be found in previous publication by Bozkurt Çolak et al. (2017). 
Irrigation systems and irrigation levels resulted in significantly different ET values in the first experimental year, but only irrigation levels had significantly different effect in the second year (Table 3). Seasonal evapotranspiration changed between $339 \mathrm{~mm}$ in $\mathrm{DI}_{50}$ with 3-day frequency treatment and $543 \mathrm{~mm}$ in $\mathrm{IF}_{3}$ FI under the SDI in the first experimental year, and $363 \mathrm{~mm}$ in $\mathrm{IF}_{6} \mathrm{DI}_{50}$ and $527 \mathrm{~mm}$ in $\mathrm{IF}_{3} \mathrm{FI}$ in the second year. In SSDI treatment plots, ET values changed between $306 \mathrm{~mm}$ in $\mathrm{IF}_{3} \mathrm{DI}_{50}$ to $495 \mathrm{~mm}$ in $\mathrm{IF}_{3}$

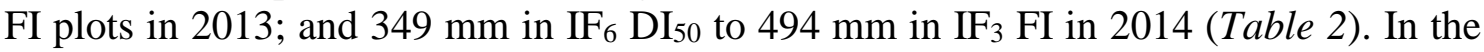
second growing season slightly lower ET values were determined compared with ET values in 2013 probably due to occurrence of the lower monthly minimum temperatures in April 2014, and prevailing high maximum air temperatures in June and August in the second season. Prevaling considerably lower air temperatures in April $\left(4.4^{\circ} \mathrm{C}\right)$ in the second year hampered the plant establishment and growth. The results revealed that $\mathrm{DI}_{50}$ plots in both drip systems resulted in an average of 3\% less crop water use values than $\mathrm{PRD}_{50}$ plots despite of receiving the same quantity of irrigation water.

Table 3. Statistical analysis results on yield of eggplant under different treatments in the experimental years

\begin{tabular}{|c|c|c|c|c|c|}
\hline Years & Irrigation Treatments & $\begin{array}{c}\text { Yield } \\
\left(\mathrm{kg} \mathrm{ha}^{-1}\right)\end{array}$ & $\begin{array}{c}\text { WUE } \\
\left(\mathrm{kg} \mathrm{m}^{-3}\right)\end{array}$ & $\begin{array}{c}\text { ET } \\
(\mathbf{m m})\end{array}$ & LAI \\
\hline \multirow{7}{*}{2013} & Irrigation systems & $\begin{array}{c}\mathrm{LSD}=1541 \\
\mathrm{P}=0.0012 * *\end{array}$ & $\mathrm{~ns}$ & $\begin{array}{l}\mathrm{LSD}=5.051 \\
\mathrm{P}=0.0001^{* *}\end{array}$ & $\begin{array}{l}\mathrm{LSD}=0.117 \\
\mathrm{P}=0.0457^{*}\end{array}$ \\
\hline & Irrigation frequency & $\begin{array}{l}\mathrm{LSD}=1245 \\
\mathrm{P}=0.0001 * *\end{array}$ & $\begin{array}{c}\mathrm{LSD}=0.12 \\
\mathrm{P}=0.0001^{* *}\end{array}$ & $\mathrm{~ns}$ & $\begin{array}{l}\mathrm{LSD}=0.045 \\
\mathrm{P}=0.0001 * *\end{array}$ \\
\hline & Irrigation levels & $\begin{array}{c}\mathrm{LSD}=1886 \\
\mathrm{P}=0.0001 * *\end{array}$ & $\begin{array}{c}\mathrm{LSD}=0.17 \\
\mathrm{P}=0.0001 * *\end{array}$ & $\begin{array}{l}\mathrm{LSD}=15.64 \\
\mathrm{P}=0.0001 * *\end{array}$ & $\begin{array}{l}\mathrm{LSD}=0.058 \\
\mathrm{P}=0.0001 * *\end{array}$ \\
\hline & Int. of irr. syst. and irr fre. & ns & $\begin{array}{c}\mathrm{LSD}=0.17 \\
\mathrm{P}=0.0001^{* *}\end{array}$ & $\mathrm{~ns}$ & $\mathrm{~ns}$ \\
\hline & Int. of irr. sys.and irr. lev. & ns & $\begin{array}{c}\mathrm{LSD}=0.24 \\
\mathrm{P}=0.0001 * *\end{array}$ & ns & ns \\
\hline & Int. of irr. fre. and irr. lev. & ns & $\begin{array}{c}\mathrm{LSD}=0.24 \\
\mathrm{P}=0.0001 * *\end{array}$ & ns & $\begin{array}{l}\mathrm{LSD}=0.083 \\
\mathrm{P}=0.0001 * *\end{array}$ \\
\hline & $\begin{array}{l}\text { Int. of irr. syst. and irr. fre. and } \\
\text { irr. lev. }\end{array}$ & ns & $\begin{array}{c}\mathrm{LSD}=0.34 \\
\mathrm{P}=0.0061 * *\end{array}$ & ns & ns \\
\hline \multirow{7}{*}{2014} & Irrigation systems & ns & $\begin{array}{c}\mathrm{LSD}=0.44 \\
\mathrm{P}=0.0080^{* *}\end{array}$ & ns & $\begin{array}{l}\mathrm{LSD}=0.049 \\
\mathrm{P}=0.0054 * *\end{array}$ \\
\hline & Irrigation frequency & $\begin{array}{c}\mathrm{LSD}=1749 \\
\mathrm{P}=0.0001 * *\end{array}$ & $\begin{array}{c}\mathrm{LSD}=0.19 \\
\mathrm{P}=0.0001 * *\end{array}$ & ns & $\begin{array}{l}\mathrm{LSD}=0.019 \\
\mathrm{P}=0.0001 * *\end{array}$ \\
\hline & Irrigation levels & $\begin{array}{c}\mathrm{LSD}=2844 \\
\mathrm{P}=0.0001 * *\end{array}$ & $\begin{array}{c}\mathrm{LSD}=0.30 \\
\mathrm{P}=0.0001 * *\end{array}$ & $\begin{array}{l}\mathrm{LSD}=15.69 \\
\mathrm{P}=0.0001 * *\end{array}$ & $\begin{array}{l}\mathrm{LSD}=0.049 \\
\mathrm{P}=0.0001 * *\end{array}$ \\
\hline & Int. of irr. syst. and irr fre. & $\begin{array}{l}\mathrm{LSD}=2473 \\
\mathrm{P}=0.0425^{*}\end{array}$ & $\begin{array}{c}\mathrm{LSD}=0.27 \\
\mathrm{P}=0.0004 * *\end{array}$ & ns & ns \\
\hline & Int. of irr. sys.and irr. lev. & ns & $\begin{array}{l}\mathrm{LSD}=0.42 \\
\mathrm{P}=0.0122 *\end{array}$ & ns & $\begin{array}{l}\mathrm{LSD}=0.069 \\
\mathrm{P}=0.0486^{*}\end{array}$ \\
\hline & Int. of irr. fre. and irr. lev. & ns & $\begin{array}{c}\mathrm{LSD}=0.42 \\
\mathrm{P}=0.0001 * *\end{array}$ & $\mathrm{~ns}$ & ns \\
\hline & $\begin{array}{l}\text { Int. of irr. syst. and irr. fre. and } \\
\text { irr. lev. }\end{array}$ & ns & $\begin{array}{c}\mathrm{LSD}=0.6 \\
\mathrm{P}=0.0115^{*}\end{array}$ & ns & ns \\
\hline
\end{tabular}

** LSD grouping at $1 \%$ level, * LSD grouping at $5 \%$ level

\section{Eggplant yield}

The fresh eggplant yields obtained from the experimental treatment plots in the study years are given in Table 2. Table 3 presents statistical analysis on the mean eggplant yields. The effects of various treatments on eggplant yield differed in the experimental 
years. Since the years were statistically different in combined variance analysis, we analyzed the data for each experimental year separately. The results indicated that irrigation systems, frequencies and levels resulted in significantly different eggplant yield values $(\mathrm{P}<0.01)$. SDI system performed better than the SSDI in the first year, however they performed similarly in the second growing season.

Eggplant yields varied from a minimum of $40.90 \mathrm{tha}^{-1}$ in subsurface drip irrigated $\mathrm{IF}_{6}$ $\mathrm{PRD}_{50}$ treatment plots to greatest $78.7 \mathrm{t} \mathrm{ha}^{-1}$ in the surface drip irrigated $\mathrm{IF}_{3} \mathrm{FI}$ in 2013 , and changed between $58.8 \mathrm{tha}^{-1}$ in $\mathrm{IF}_{6} \mathrm{PRD}_{50}$ in SSDI and $92.7 \mathrm{tha}^{-1}$ in the IFF FI in SSDI 2014 growing season. PRD $_{50}$ treatments produced the least yields in the experimental years. The second growing season resulted in significantly higher yields than in the first season because of prevailing favourable climatic conditions in the 2014 .

\section{Water use efficiency}

Water use efficiency values were significantly affected by drip irrigation systems, irrigation frequencies and levels in the experimental years (Table 3). WUE values varied between $12.2 \mathrm{~kg} \mathrm{~m}^{-3}$ in $\mathrm{IF}_{6} \mathrm{PRD}_{50}$ under SSDI and $21.9 \mathrm{~kg} \mathrm{~m}^{-3}$ in the $\mathrm{IF}_{3} \mathrm{DI}_{50}$ in SSDI in 2013 and ranged from $16.6 \mathrm{~kg} \mathrm{~m}^{-3}$ in the $\mathrm{IF}_{6} \mathrm{PRD}_{50}$ treatment under SDI to $24.5 \mathrm{~kg} \mathrm{~m}^{-3}$ in the $\mathrm{IF}_{3} \mathrm{DI}_{50}$ under SSDI in 2014. The results revealed that WUE increased with decreasing irrigation water amounts except in the $\mathrm{PRD}_{50}$ treatment which resulted in minimum WUE values in both growing seasons.

\section{Dry matter yield and leaf area index}

The evolution of the dry matter yield with time for different treatments under the surface and subsurface drip systems in the experimental is depicted in Fig. 4a-d. The $\mathrm{IF}_{3} \mathrm{FI}$ under the SDI system resulted in the maximum dry matter yield of 6329 and 6400 $\mathrm{kg} \mathrm{ha}^{-1}$ in 2013 and 2014 growing seasons, respectively; and the least dry matter yields were observed in the $\mathrm{IF}_{6} \mathrm{PRD}_{50}$ treatment under the SSDI.
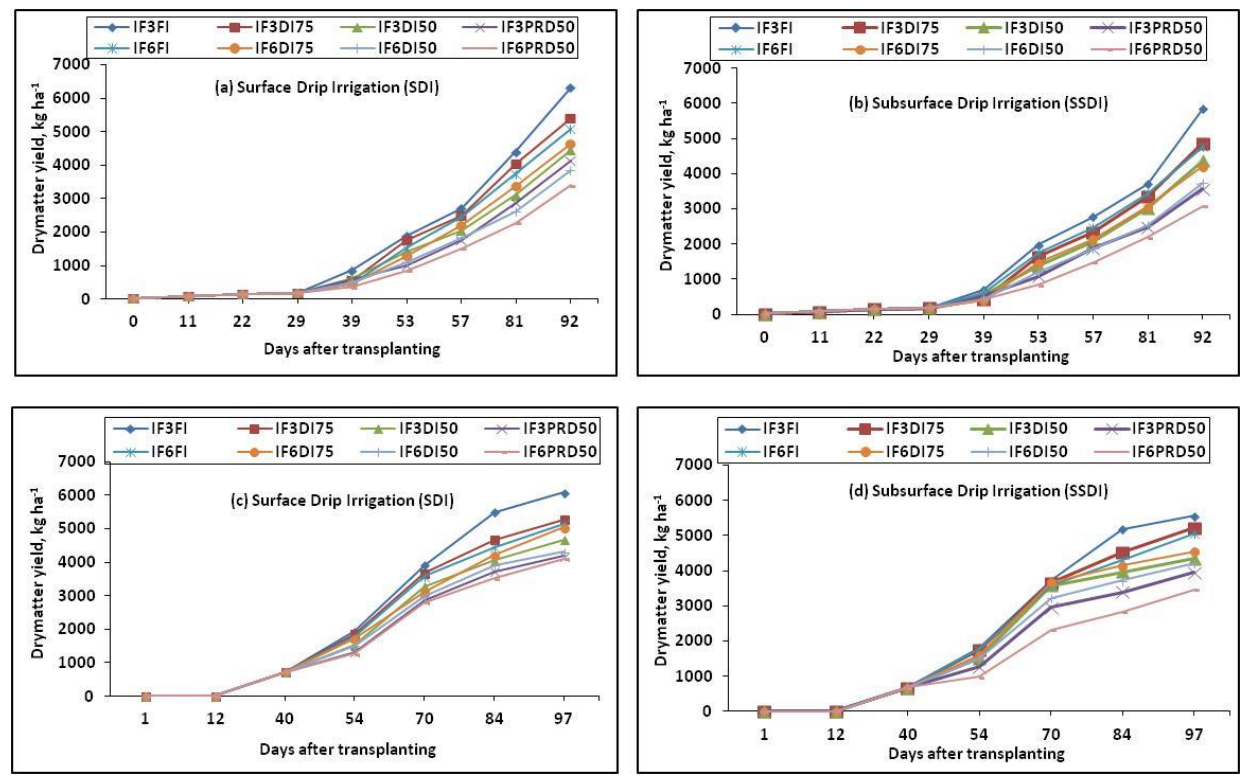

Figure 4. Dry matter yield variation during the 2013 and 2014 eggplant growing season in all treatments under surface and subsurface drip irrigation. (a) SDI, 2013; (b) SSDI, 2013; (c) SDI, 2014; (d) SSDI, 2014 
The maximum leaf area index (LAI) values for the different treatments under both drip systems in the experimental years are presented in Table 2. Irrigation systems, frequency and level resulted in significantly different LAI values (Table 3). The $\mathrm{IF}_{3}$ FI treatment under SDI produced the maximum LAI of 4.13 and 4.30 in the first and second growing seasons, respectively; the minimum LAI values of 2.6 and 2.1 were observed in the $\mathrm{IF}_{6}$ $\mathrm{PRD}_{50}$ treatment under SSDI in 2013 and 2014, respectively.

\section{Stomatal resistance}

Stomatal resistance $\left(\mathrm{r}_{\mathrm{s}}\right)$ evolution with time in the experimental years for different treatments under SDI and SSDI systems are depicted in Fig. 5a-d, respectively. The stomatal resistances showed tendency to increase with increasing water stress. Smaller $r_{s}$ values were observed in FI plots under the two drip systems with 3-day irrigation frequency than $\mathrm{DI}_{50}$ and $\mathrm{PRD}_{50}$ treatments with 6-day irrigation frequency. Generally, the lower $r_{s}$ value was measured in the beginning of the growing season, and the $r_{s}$ rises towards the end of the growing season. In the SDI treatments, stomatal resistance values ranged between $40 \mathrm{~s} \mathrm{~m}^{-1}$ in $\mathrm{IF}_{3} \mathrm{FI}$ and $132 \mathrm{~s} \mathrm{~m}^{-1}$ in $\mathrm{IF}_{6} \mathrm{PRD}_{50}$ in 2013, and varied between $36 \mathrm{~s} \mathrm{~m}^{-1} \mathrm{IF}_{3} \mathrm{FI}$ and $136 \mathrm{~s} \mathrm{~m}^{-1} \mathrm{IF}_{6} \mathrm{PRD}_{50}$ in the 2014. In SSDI plots, $\mathrm{r}_{\mathrm{s}}$ values varied between $34 \mathrm{~s} \mathrm{~m}^{-1} \mathrm{IF}_{3} \mathrm{FI}$ plots and $121 \mathrm{~s} \mathrm{~m}^{-1} \mathrm{IF}_{6} \mathrm{PRD}_{50}$ in 2013, and varied from $30 \mathrm{~s} \mathrm{~m}^{-1} \mathrm{IF}_{3} \mathrm{FI}$ to $132 \mathrm{~s} \mathrm{~m}^{-1} \mathrm{IF}_{6} \mathrm{PRD}_{50}$ in the 2014. Higher stomatal resistance values were observed in the $\mathrm{PRD}_{50}$ than those in the $\mathrm{DI}_{50}$ plots under both drip irrigation systems. We also observed that the values of stomatal resistance $\left(r_{s}\right)$ in SSDI plots were slightly lower than those of SDI plots in general.
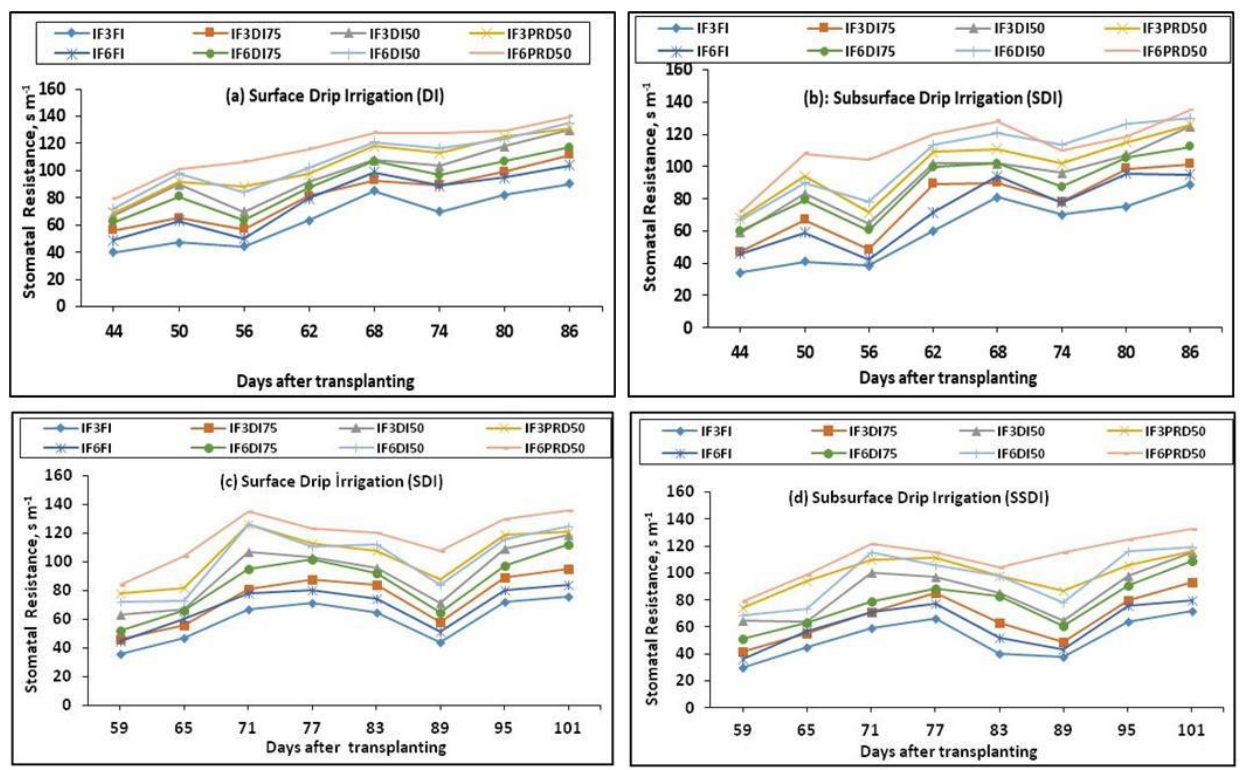

Figure 5. Stomatal resistance variation during the experimental years in all treatments. (a) Surface drip irrigation (2013); (b) Subsurface drip irrigation (2013); (c) Surface drip irrigation (2014); (d) Subsurface drip irrigation (2014)

Diurnal variation of stomatal resistance values for the different treatments in the study years are presented in Figure $6 a-d$, respectively. As shown in these figures rs values were lower in the morning hours and gradually increased with time and reached their maximum at solar noon time (13:00-14:00). Then $r_{s}$ values started to decrease towards the sunset 
time in all treatments due to lower air temperatures. The lowest rs values were observed in the $\mathrm{IF}_{3} \mathrm{FI}$ plot in both study years; maximum $\mathrm{r}_{\mathrm{s}}$ values were measured in $\mathrm{IF}_{6} \mathrm{PRD}_{50}$ and $\mathrm{IF}_{6} \mathrm{DI}_{50}$ treatments.
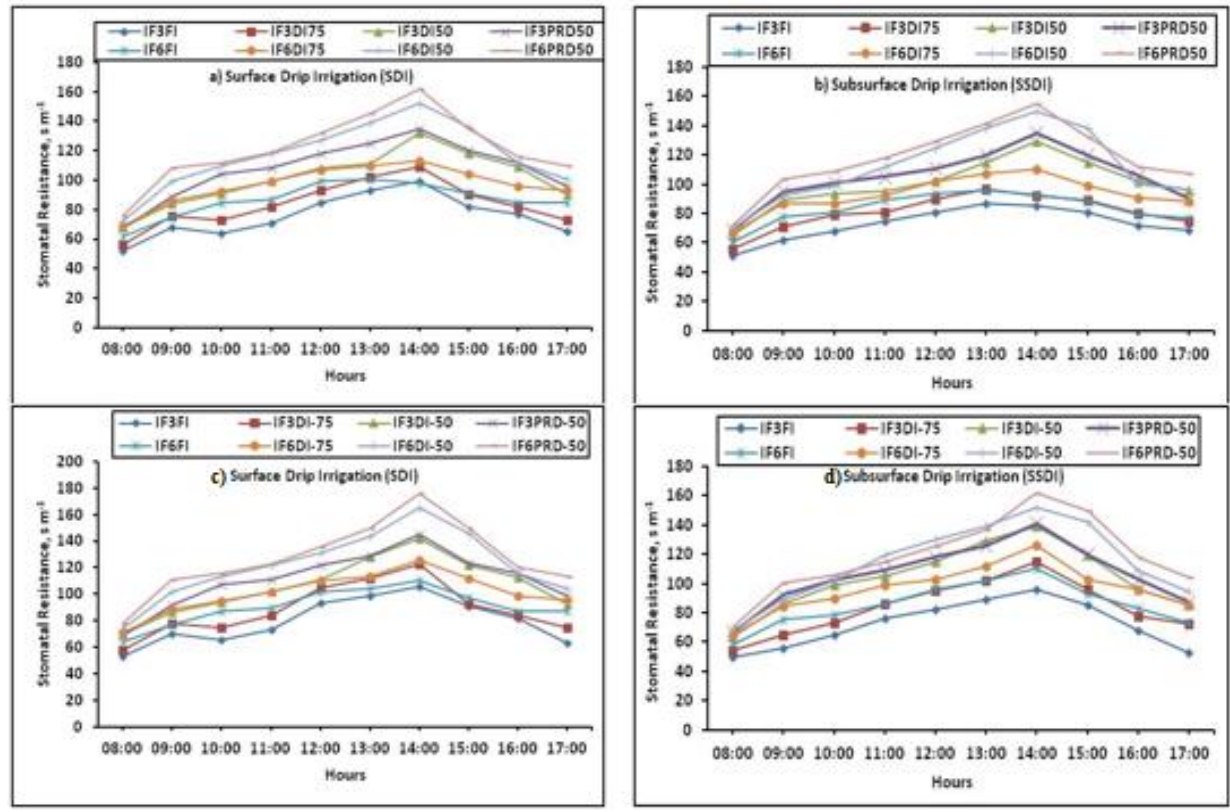

Figure 6. Diurnal variation of stomatal resistance values in all treatments. (a) Surface drip irrigation (2013); (b) Subsurface drip irrigation (2013); (c) Surface drip irrigation (2014); (d) Subsurface drip irrigation (2014)

\section{Relations between soil water content, yield, dry matter, evapotranspiration, water use efficiency and stomatal resistance}

The relationships between soil water content and stomatal resistance $\left(r_{s}\right)$ prior to irrigations in treatments in the 2013 and 2014 growing seasons for surface and subsurface drip systems are depicted in Fig. 7a-d, respectively. Mean stomatal resistance was calculated by taking average of the readings taken before irrigation throughout the growing season.

Significant second order polynomial relations were obtained between soil water content in the effective root-zone depth and stomatal resistance in the experimental years. Stomatal resistance values decreased as the soil water content increased towards the field capacity $(245 \mathrm{~mm})$ under both drip systems.

The relationships between mean stomatal resistance and total eggplant yield values for SDI and SSDI treatments in the experimental years are presented in Fig. 8. Significant relations were found between fresh eggplant yield and stomatal resistance. The relationship between yield and stomatal resistance was expressed with a second order polynomial in the first year $\left(\mathrm{R}^{2}=0.66\right)$, and strong linear equation in the second year $\left(\mathrm{R}^{2}=0.83\right)$. Sezen et al. (2019) also expressed significant relationships among the stomatal resistance, evapotranspiration and red pepper yield in the Mediterranean region.

The relationship between stomatal resistance and dry matter yield for SDI and SSDI treatment plots were presented in Fig. 9. We found significant linear relations between 
dry matter yield and stomatal resistance for eggplant with the coefficient of determination $\left(\mathrm{R}^{2}\right)$ for the stomatal resistance was 0.84 and 0.85 in 2013 and 2014, respectively.

The relationships between stomatal resistance and evapotranspiration for SDI and SSDI treatments were shown in Fig. 10. We found significant linear equations between evapotranspiration and stomatal resistance for eggplant with the coefficient of determination $\left(\mathrm{R}^{2}\right)$ for the stomatal resistance was 0.68 and 0.74 in 2013 and 2014, respectively. Liu et al. (2016) reported that transpiration rate linearly increased with increasing stomatal conductance. It was observed that plants experiencing water deficit generally increase $r_{s}$, thereby decreasing transpiration rate, increasing leaf temperatures (Ballester et al., 2013).

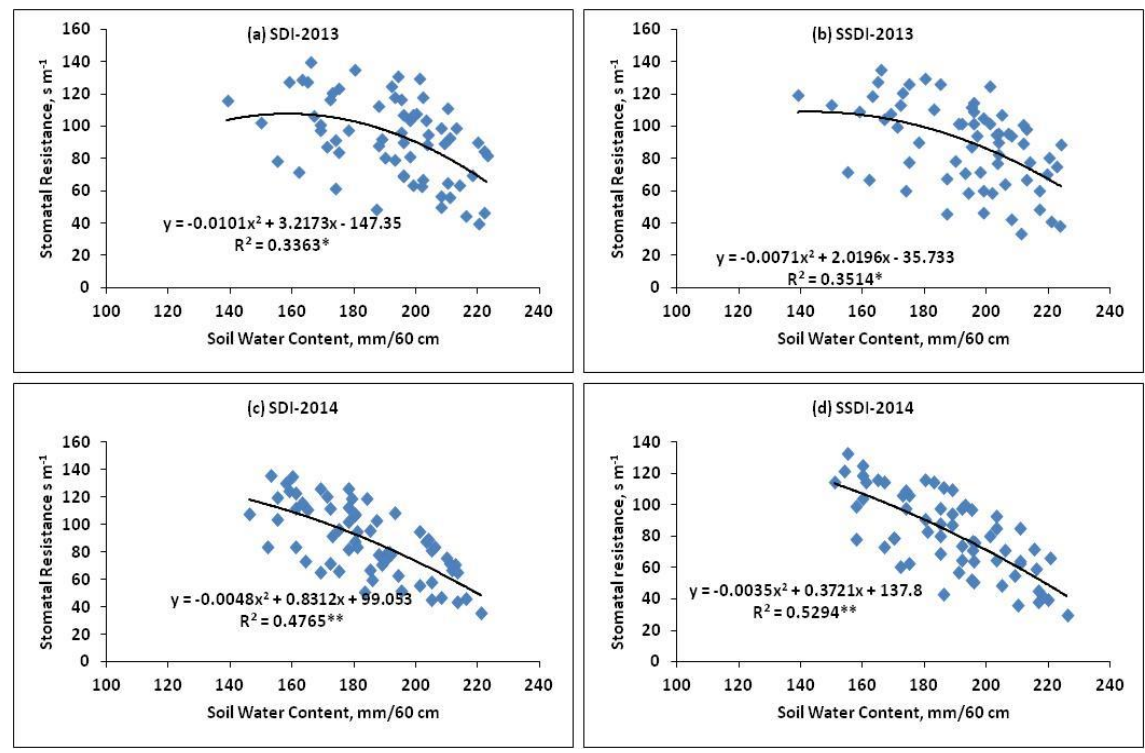

Figure 7. The relationship between soil water content and stomatal resistance ( $r s)$ in treatments in the experimental years (a) SDI-2013; (b) SSDI-2013; (c) SDI-2014; (d) SSDI-2014

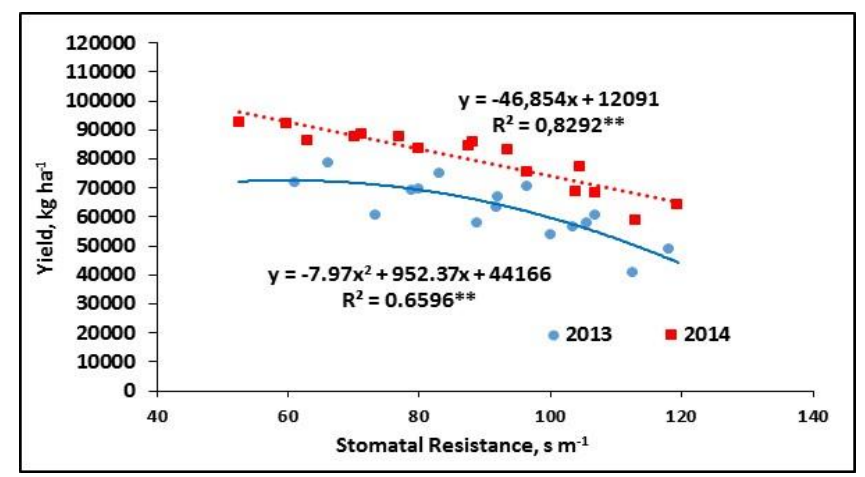

Figure 8. The relationship between total yield and stomatal resistance in the 2013 and 2014 growing seasons

The relationships between stomatal resistance and water use efficiency values for SDI and SSDI treatment plots were depicted in Fig. 11. We found significant second order equations between WUE and stomatal resistance for eggplant with the coefficient of determination $\left(\mathrm{R}^{2}\right)$ for the rs was 0.27 and 0.42 in 2013 and 2014, respectively. The 
relationship between LAI and stomatal resistance for the different treatments were depicted in Figure 12. Significant linear relation was obtained between LAI and rs for the 2013 and 2014 growing seasons with high coefficient of determination $\left(\mathrm{R}^{2}\right)$ values as 0.90 and 0.84 , respectively.

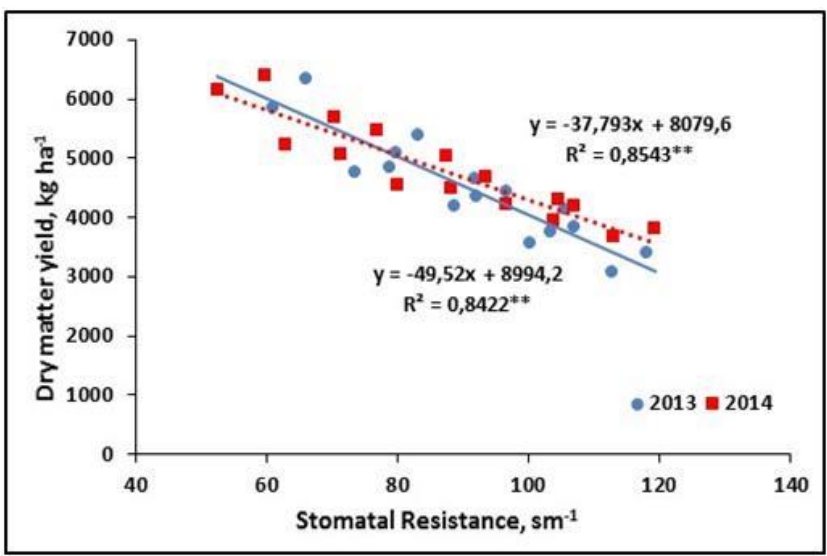

Figure 9. The relationship between dry matter yield and stomatal resistance ( $r s$ ) in the 2013 and 2014 growing seasons in all treatments

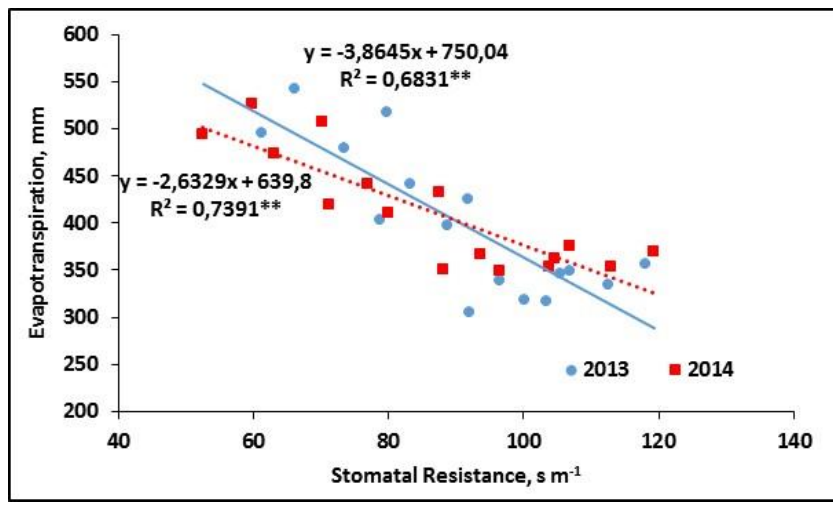

Figure 10. The relationship between ET and stomatal resistance in the 2013 and 2014 growing seasons

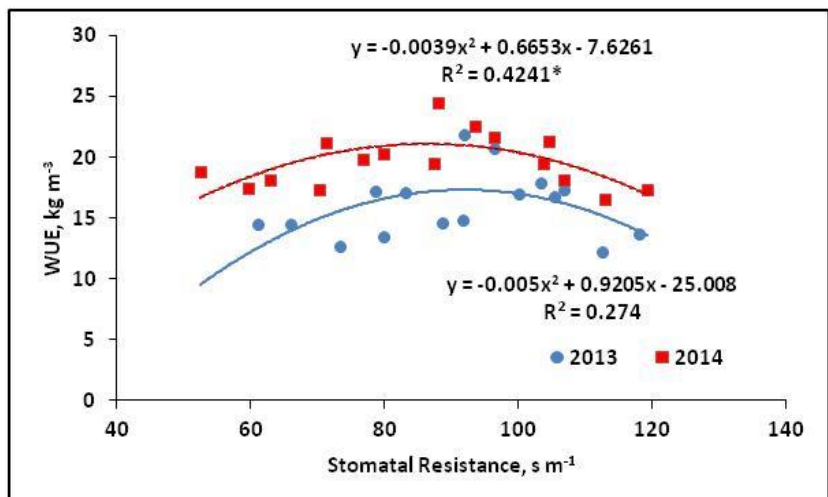

Figure 11. The relationship between WUE and stomatal resistance in the 2013 and 2014 growing seasons 


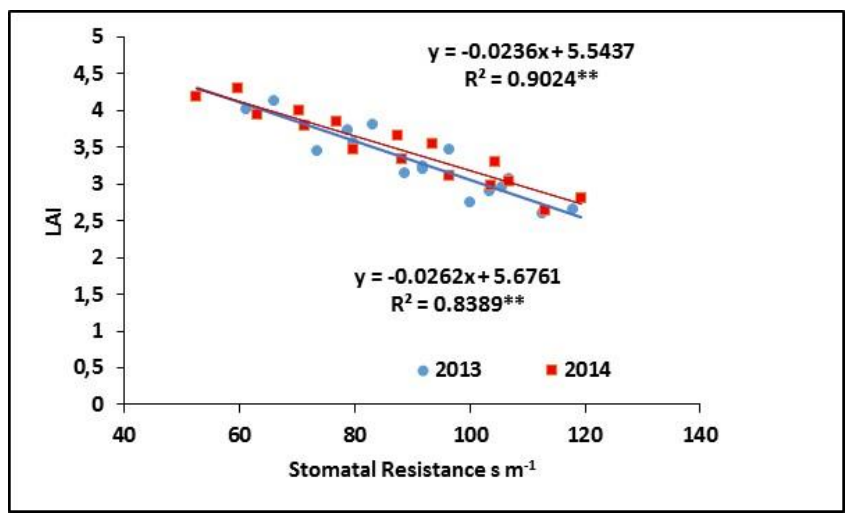

Figure 12. The relationship between LAI and stomatal resistance in the 2013 and 2014 growing seasons

\section{Discussions}

Studies were made to see whether physiological responses of SDI and SSDI irrigated eggplant to full and various deficit irrigation regimes and frequencies could be utilized for irrigation scheduling.

The research results revealed that the effects of SDI and SSDI systems, irrigation frequencies and levels were found to be significant on total yield and evapotranspiration of eggplant for obtaining greater yield in the Mediterranean environment.

The full irrigation with more frequent irrigation frequency (3-day) under the two drip systems produced significantly greater eggplant yields, followed by $\mathrm{DI}_{75}$ treatment which produced slightly lower yield (about 5\%) than FI in both experimental years but resulted in water saving of $22.5 \%$. The improved yield under high irrigation frequency as observed in our experiment might be due to the enhanced nutrients uptake (Silber et al., 2003; Ta et al., 2012), consistent with studies on tomato (Pires et al., 2011; Rodriguez-Ortega et al., 2017) and other crops such as bell pepper (Sezen et al., 2006) and melon (Sensoy et al., 2007).

The results revealed that water stress occurring in $\mathrm{DI}_{50}$ and $\mathrm{PRD}_{50}$ treatments under both drip systems resulted in decreased eggplant yield significantly. These reductions for 6-day irrigation frequency were much greater than those in 3-day frequency. Our findings are in agreement with those found by Kirnak et al. (2002) who reported that deficit irrigations caused a decrease in yield and fruit size of eggplant. The most sensitive growth periods of eggplant to water stress are during flowering and fruit formation. Therefore, occurrence of any water stress in these growth stages might lead to the development of blossom end rot and malformed fruits. Kemble et al. (1998) reported that fruit size and yield as well as dry matter yield (Sarker et al., 2005) are decreased by water stress. Aujla et al. (2007) obtained eggplant yields changing between 43.10 and $103.10 \mathrm{t} \mathrm{ha}^{-1}$ in India; Kuşcu et al. (2009) reported maximum marketable eggplant yield of $46.40 \mathrm{t} \mathrm{ha}^{-1}$ when irrigations were scheduled at $80 \%$ replenishment of the evaporation form Class A pan in Turkey. Karam et al. (2011) determined fresh eggplant yields changing from 13.40 to $33.80 \mathrm{t} \mathrm{ha}^{-1}$ for full and deficit irrigations under Lebanease conditions. Douh and Boujelben (2010) investigated the effects of subsurface and surface drip systems on eggplant yield Tunisia and they concluded that SSDI had better performance than SDI. Rakhymzhanov et al. (2015) reported that drip irrigation produced $41 \%$ greater yield than 
furrow method and resulted in water saving of $29 \%$ as compared to furrow irrigation in Kazakhstan.

Three-day irrigation frequency $\left(\mathrm{IF}_{3}\right)$ produced significantly higher yields than six-day $\left(\mathrm{IF}_{6}\right)$ frequency for the corresponding treatments. The reason for greater yield under the more frequent irrigations is that plants can uptake water more easily without experiencing any stress effect compared with longer irrigation frequency treatments. There was no significant difference between the SDI and SSDI systems with regard to eggplant yields although SDI performed slightly better than the SSDI in the first year but they performed similarly in the second year. The results indicated that both SDI and SSDI full irrigation with 3-day irrigation frequency $\left(\mathrm{IF}_{3} \mathrm{FI}\right)$ treatment can be recommended. Deficit irrigation $\mathrm{DI}_{50}$ and PRD50 produced lowest eggplant yields. Although the $\mathrm{DI}_{75}$ received approximately $22.5 \%$ less water as compared to the FI, yield was reduced only by an average of $4.3 \%$. Therefore, considering water deficiency in dry years $\mathrm{DI}_{75}$ irrigation practices can be a good alternative for high yields. The physiological response of eggplant to different water stress levels can be used for optimization and sustainability of crop production in areas where water sources are limited or expensive.

The 3-day irrigation frequency produced higher dry matter yields than the 6-day frequency treatments in both drip methods. The significantly greater reduction in dry matter yields for plants under water stress in $\mathrm{DI}_{50}$ and $\mathrm{PRD}_{50}$ treatments during fruit ripening stage might be due to decrease in fruit dry-matter yields, as reported by Chaves et al. (2003), and Lovelli et al. (2007). Passioura and Angus (2010) indicated that decreases in plant growth in semi-arid agriculture might be the results of reductions in assimilate transfer from leaves to fruits due to increasingly unfavourable water supply conditions. This observation is apparently pertinent to eggplant produced under water stress conditions.

Water stress resulted in lower leaf area index values under both SDI and SSDI treatments in the experimental years. Madramootoo and Rigby (1991) indicated that water stress reduced the leaf areas of eggplants. Karam et al. (2011) observed the highest LAI in the full irrigation plots, while 44 and $10 \%$ reductions were reported for deficit irrigations. Mohawesh (2016) found that water deficit resulted in reduction in growth of eggplant which in turn reduced LAI. The main reason for the decreased vegetative growth of vegetable crops under water stress might be acceleration of leaf senescense, as pointed out by Kirnak et al. (2002) on eggplant and Karam et al. (2009) on bell pepper plants. Passioura and Angus (2010) demonstrated that under water stress, the life cycles of annual plants are shortened and leaf senescense accelerated due to reduced water uptake by the roots. These findings are similar with our results obtained in the present study.

Our finding indicated that the highest WUE was not associated with the least irrigation quantity is because increasing water stress hindered plant growth and consequently reduced the final yield, consistent with previous studies on tomato, and eggplant (Kang et al., 2004; Cantore et al., 2016). Similarly, the minimum WUE was not associated with the highest irrigation amount because it enhanced non-productive transpiration, alluding that increasing irrigation amount benefited yield but not WUE (Du et al., 2017). It is suggested that high WUE should be associated with high (or acceptable) yields, particularly in water scarce areas. Karam et al. (2011) reported the maximum WUE in the deficit irrigated plots as $5.6 \mathrm{~kg} \mathrm{~m}^{-3}$ in Lebanon, while Lovelli et al. (2007) observed the greatest WUE value of $10.3 \mathrm{~kg} \mathrm{~m}^{-3}$ in full irrigation in Italy. Other researchers reported increased WUE in deficit irrigation treatments for red pepper (Sezen et al., 2014), eggplant (Kirnak et al., 2002). The reason for greater WUE in crops under water stress is 
because stressed plants wilt far more than unstressed plants and wilting invariably occurs in times when the vapour pressure deficit of the atmosphere is large (Bloch et al., 2006).

It was observed that slightly lower rs values were recorded for SSDI plots than the SDI treatments in general. Stomatal resistance values influenced by changing weather conditions especially they were sensitive to changes in vapour pressure deficit, wind speed, and air temperature as well as soil water content variation at measurement times. Thus, this parameter fluctuates significantly with changing soil water and weather conditions. Therefore, utilizing rs values for irrigation scheduling requires considerable attention for reliable and practical applications.

Weng et al. (2011) stated that stomata play a significant role in determining the carbon and water cycle between the plants and the atmosphere. One of the first physiological responses of plants exposed to water restriction is to control the stomatal opening and closing movements in order to decrease water loss via transpiration. However, since $\mathrm{CO}_{2}$ entry is also inhibited, the photosynthesis activity of the plant is directly affected by these movements (Arve et al., 2011). It is noted that water stress decrease stomatal conductance (gs) and transpiration rate ( $\mathrm{Tr}$ ), and the photosynthesis rate primarily decreased in response to reduced stomatal conductance (Ma et al., 2015). It is also mentioned that lower stomatal conductance would decrease $\mathrm{CO}_{2}$ assimilation very slightly, however would significantly reduce $\mathrm{Tr}$, since transpiration rises linearly with stomatal conductance, due to constant difference in water vapor concentration between leaves and the air (Liu et al., 2016).

In this study, the evapotranspiration rates of the eggplant reduced with decreasing amount of applied irrigation water, resulting in increased stomatal resistance and subsequent reduction in yield and plant growth. These results confirm many earlier studies on different crops (Ma et al., 2015; Liu et al., 2016). Thus, our findings demonstrated that the stomatal resistance is a good indicator for describing the plant water status.

Water shortage resulted in greater stomatal resistance values. The current study results demonstrated that there were strong linear relations among the yield, dry matter yield and stomatal resistance (rs). In addition, we found strong significant linear relations between crop water use (ET) and stomatal resistance. Significant curvilinear relationships were obtained between the soil water content and WUE and rs. All these relations indicated that an average value of $60 \mathrm{~s} \mathrm{~m}^{-1}$ stomatal resistance value prior to irrigation is the threshold value for irrigation scheduling of eggplants. Since rs values were lower in the early season and increased towards the end of season as shown in Figs. 5 and 6, rs value range of 30-40 s m${ }^{-1}$ in the vegetative stage until flowering; 40-60 $\mathrm{s} \mathrm{m}^{-1}$ during flowering and yield formation stage, and 60-80 $\mathrm{s} \mathrm{m}^{-1}$ during late growth stage can be used for irrigation scheduling purpose.

\section{Conclusions}

Studies were made to see whether physiological responses such as stomatal resistance of SDI and SSDI irrigated eggplant to full and various deficit irrigation regimes and frequencies could be utilized for irrigation scheduling. Water shortage resulted in greater stomatal resistance values. The current study results demonstrated that there were strong linear relations among the yield, dry matter yield and stomatal resistance (rs). In addition, we found strong significant linear relations between crop water use (ET) and stomatal resistance. Curvilinear relationships were obtained between the WUE and rs. 
Stomatal resistance values in subsurface drip irrigated eggplant were generally lower than those in the surface drip irrigated plots. Frequent irrigations also resulted in lower stomatal resistance values when compared with 6-day irrigation frequency in this study. Lower rs values were observed in FI plots under two drip systems with 3-day frequency than $\mathrm{DI}_{50}$ and $\mathrm{PRD}_{50}$ plots and 6-day frequency. The results indicated that threshold value of stomatal resistance was approximately $60 \mathrm{~s} \mathrm{~m}^{-1}$ for eggplant for irrigation scheduling. Therefore, it is proved that rs can be used for irrigation scheduling. The predicting the yield response to stomatal resistance is important for developing strategies and making decisions for use by farmers as well as researchers for managing irrigation under scarce water resources conditions.

The research results also revealed that the effects of SDI and SSDI systems, irrigation frequencies and levels were found to be significant on total yield and evapotranspiration of eggplant for obtaining greater yield in the Mediterranean environment. The results indicated that both SDI and SSDI full irrigation with 3-day irrigation frequency $\left(\mathrm{IF}_{3} \mathrm{FI}\right)$ treatment can be recommended. Deficit irrigation $\mathrm{DI}_{50}$ and $\mathrm{PRD}_{50}$ produced lowest eggplant yields. Although the $\mathrm{DI}_{75}$ received approximately $22.5 \%$ less water as compared to the FI, yield was reduced only by an average of $4.3 \%$. Therefore, considering water deficiency in dry years $\mathrm{DI}_{75}$ irrigation practices can be a good alternative for high yields. The physiological response of eggplant to different water stress levels can be used for optimization and sustainability of crop production in areas where water sources are limited or expensive.

Acknowledgement. The authors would like to thank the Turkish Scientific and Technical Research Council (TUBITAK) for its financial support for the project TOVAG-1120870.

\section{REFERENCES}

[1] Agele, S., Shabtai Cohen, S., Assouline, S. (2006): Hydraulic characteristics and water relations of net house-grown bell pepper as affected by irrigation regimes in a Mediterranean climate. - Environ. Exp. Bot. 57: 226-235.

[2] Anjum, S. A., Xie, X. Y., Wang, L. C., Saleem, M. F., Man, C., Lei, W. (2011): Morphological, physiological and biochemical responses of plants to drought stress. - Afr. J. Agric. Res. 6: 2026-2032.

[3] Arve, L. E., Torre, S., Olsen, J. E., Tanino, K. K. (2011): Stomatal Responses to Drought Stress and Air Humidity, Abiotic Stress in Plants. - In: Shanker, A. (ed.) Mechanisms and Adaptations. ISBN: 978-953-307-394-1, InTech, p 428.

[4] Aujla, M. S., Thind, H. S., Buttar, G. S. (2007): Fruit yield and water use efficiency of eggplant (Solanum Melongema L.) as influenced by different quantities of nitrogen and water applied through drip and furrow irrigation. - Scientia Horticulturae 112: 142-148.

[5] Ballester, C., Jimenez-Bello, M. A. Castel, J. R., Intrigliolo, D. S. (2013): Usefulness of thermography for plant water stress detection in citrus and persimmon trees. - Agric. For. Meteorol. 168: 120-129.

[6] Behboudian, M. H. (1977): Responses of eggplant to drought. I. Plant water balance. Scientia Horticulturae 7(4): 303-31.

[7] Berry, J. A., Beerling, D. J., Franks, P. J. (2010): Stomata: key players in the earth system, past and present. - Curr. Opinion Plant Biol. 13: 233-240.

[8] Bloch, D., Hoffmann, C. M., Marlander, B. (2006): Impact of water supply on photosynthesis, water use and carbon isotope discrimination of sugar beet genotypes. - Eur. J. Agron. 24: 218-225. 
[9] Bozkurt Çolak, Y., Yazar, A., Sesveren, S., Colak, I. (2017): Evaluation of yield and leaf water potantial (LWP) for eggplant under varying irrigation regimes using surface and subsurface drip systems. - Scientia Horticulturae 219: 10-21.

[10] Bozkurt, S., Sayilikan Mansuroğlu, G. (2018): Response of unheated greenhouse grown green bean to buried drip tape placement depth and watering levels. - Agricultural Water Management 197: 1-8.

[11] Brodribb, T. J., McAdam, S. A. (2011): Passive origins of stomatal control in vascular plants. - Sci. 331: 582-585.

[12] Cantore. V., Lechkar, O., Karabulut, E., Sellami, M. H., Albrizio, R., Boari, F., Stellacci, A. M., Todorovic, M. (2016): Combined effect of deficit irrigation and strobilurin application on yield, fruit quality and water use efficiency of "cherry" tomato (Solanum lycopersicum L.). - Agricultural Water Management 167: 53-61.

[13] Chartzoulakis, K., Drosos, N. (1995): Water use and yield of greenhouse grown eggplant under drip irrigation. - Agricultural Water Management 28: 113-120.

[14] Chaves, M. M., Maroco, J, P., Pereira, J. S. (2003): Understanding plant responses to drought from genes to whole plant. - Funct. Plant Biol. 30: 239-264.

[15] Clauw, P., Coppens, F., De Beuf, K., Dhondt, S., Van Daele, T., Maleux, K., Inze, D. (2015): Leaf responses to mild drought stress in natural variants of Arabidopsis thaliana. Plant Physiol doi: 10.1104/pp.114.

[16] Clawson, K. L., Blad, B. L. (1982): Infrared thermometry for scheduling irrigation of corn. - Agronomy Journal 74(2): 311-316.

[17] Diaz-Perez, J. C., Eaton, T. E. (2015): Eggplant (Solanum melongena L.) plant growth and fruit yield as affected by drip irrigation rate. - Hortscience 50(11): 1709-1714.

[18] Douh, B., Boujelben, A. (2010): Water saving and eggplant response to subsurface drip irrigation. - Agricultural Segment: 1(2) AGS/1525.

[19] Du, Y., Cao H., Liu, S., Gu, X., Cao, Y. (2017): Response of yield, quality, water and nitrogen use efficiency of tomato to different levels of water and nitrogen under drip irrigation in Northwestern China. - Journal of Integrative Agriculture 16: 1153-1161.

[20] English, M. J., Salomon, K. H., Hoffman, G. J. (2002): A paradigm shift in irrigation management. - J. Irrigation and Drainage Engineering 128(5): 267-277.

[21] Gaveh, E. A., Timpo, G. M., Agodzo, S. K., Shin, D. H. (2011): Effect of irrigation, transplant age and season on growth, yield and irrigation water use efficiency of the African eggplant. - J. Hort. Environ. Biotechnol. 52: 13-28.

[22] Gerosa, G., Mereu, S., Finco, A., Marzuoli, R. (2012): Stomatal conductance modeling to estimate the evapotranspiration of natural and agricultural ecosystems. - In: Irmak, A. (ed.) Evapotranspiration-Remote Sensing and Modeling. Intech. 403-420.

[23] Gong, D., Mei, X., Hao, W., Wang, H., Caylor, K. K. (2017): Comparison of multi-level water use efficiency between plastic film partially mulched and non- mulched croplands at eastern Loess Plateau of China. - Agric. Water Manage. 179: 215-226.

[24] Goodwin, I., Boland, A. M. (2002): Scheduling deficit irrigation of fruit trees for optimizing water use efficiency. - In: Deficit Irrigation Practices, Water Reports, FAO.

[25] Kang, Y., Wang, F. X., Liu, H. J., Yuan, B. Z. (2004): Potato evapotranspiration and yield under different drip irrigation regimes. - Irrigation Science 23: 133-143.

[26] Karam, F., Masaad, R., Bachour, R., Rhayem, C., Rouphael, Y. (2009): Water and radiation use efficiencies in drip irrigated pepper (Capsicum annuиm L.): response to full and deficit irrigation regimes. - Eur. J. Hortic. Sci. 74: 79-85.

[27] Karam, F., Sabiha, R., Skaf, S., Breidy, J., Rouphael, Y., Balendonck, J. (2011): Yield and water use of eggplants (Solanum Melongena L.) under full and deficit irrigation regimes. - Agricultural Water Management 98: 1307-1316.

[28] Kemble, J. M., Sikora, E. J., Simonne, E. H., Zehnder, G. W., Patterson, M. G. (1998): Guide to Commercial Eggplant Production. - Agronomy and Soils, all at Auburn Univ. ANR-1098. 
[29] Kırnak, H., Taş, İ., Kaya, C., Higgs, D. (2002): Effects of deficit irrigation on growth, yield and fruit quality of eggplant under semi-arid conditions. - Aust. J. Agric. Res. 53: 13671373.

[30] Kong, Q., Li, G., Wang, Y., Hua, H. (2012): Bell pepper response to surface and subsurface drip irrigation under different fertigation levels. - Irrig Sci. 30: 233-245.

[31] Kuşçu, H., Çetin, B., Turhan, A. (2009): Yield and economic return of drip-irrigated vegetable production in Turkey. - New Zealand Journal of Crop and Horticultural Science 37: 51-59.

[32] Lamm, F. R., Camp, C. R. (2007): Design, Operation, and Management, Subsurface Drip Irrigation. - In: Lamm, F. R., Ayars, J. E., Nakayama, F. S. (eds.) Microirrigation for Crop Production. Elsevier, Amsterdam, The Netherlands, pp 473-551.

[33] Lianga, Y. L., Wu, X., Zhu, J. J., Zhou, M. J., Peng, Q. (2011): Response of hot pepper (Capsicum annuum L.) to mulching practices under planted greenhouse condition. - Agric. Water Manage. 99: 111-120.

[34] Liu, E. K., Mei, X. R., Yan, C. R., Gong, D. Z., Zhang, Y. Q. (2016): Effects of water stress on photosynthetic characteristics, dry matter translocation and WUE in two winter wheat genotypes. - Agric. Water Manage. 167: 75-85.

[35] Lovelli, S., Perniola, M., Ferrara, A., Di Tommaso, T. (2007): Yield response factor to water (Ky) and water use efficiency of Carthamus tinctorius L. and Solanum melongena L. - Agric. Water Manage. 92: 73-80.

[36] Ma, S. C., Duan, A. W., Wang, R., Guan, Z. M., Yang, S. J., Ma, S. T., Shao, Y. (2015): Root-sourced signal and photosynthetic traits dry matter accumulation and remobilization, and yield stability in winter wheat as affected by regulated deficit irrigation. - Agric. Water Manage. 148: 123-129.

[37] Madramootoo, C. A., Rigby, M. (1991): Effects of trickle irrigation on the growth and sunscald of bell peppers (Capsicum annuum L.) in southern Quebec. - Agric. Water Manage. 19: 181-189.

[38] Makbul, S., Saruhan-Guler, N., Durmus, N., Guven, S. (2011): Changes in anatomical and physiological parameters of soybean under drought stress. - Turk. J. Bot. 35: 369-377.

[39] Mohawesh, O. (2016): Utilizing deficit irrigation to enhance growth performance and water-use efficiency of eggplant in arid environments. - Journal of Agricultural Science and Technology 18(1): 265-276.

[40] Müller, T., Ranquet Bouleau, C., Perona, P. (2016): Optimazing drip irrigation for eggplant crops in semi-arid zones using evolving thresholds. - Agric. Water Mange. 177: 54-65.

[41] Nemeskeri, E., Molnar, K., Vigh, R., Nagy, J., Dobos, A. (2015): Relationships between stomatal behaviour, spectral traits and water use and productivity of green peas (Pisum sativum L.) in dry seasons. - Acta Physiol Plant 37: 1-16.

[42] Osakabe, Y., Osakabe, K., Shinozaki, K., Tran, L. S. P. (2014): Response of plants to water stress. - Frontiers Plant Sci. 5: 1-8.

[43] Passioura, J. B., Angus, J. F. (2010): Improving productivity of crops in water-limited environments. - In: Sparks, D. L. (ed.) Advances in Agronomy 106: 37-75.

[44] Pérez-Pérez, J. G., Romero, P., Navarro, J. M., Botía, P. (2008): Response of sweet orange $\mathrm{cv}$ 'lane late' to deficit irrigation in two rootstocks. I: water relations, leaf gas exchange and vegetative growth. - Irrig. Sci. 26(5): 415-425.

[45] Pires, R. C. M., Furlani, P. R., Ribeiro, R. V., Bodine Junior, D., Sakai, E., Lourenção, A. L., Neto, A. T. (2011): Irrigation frequency and substrate volume effects in the growth and yield of tomato plants under greenhouse conditions. - Scientia Agricola 68: 400-405.

[46] Rakhymzhanov, B. S., Aitbaev, T. E., Tazhibaev, T. S., Cholacov, T. L. (2015): Cultivation of egg plant (Solanum melongena L.) using drip irrigation with the use of mineral fertilizers in the conditions of the South-east Kazakhstan. - Biosciences Biotechnology Research Asia 12(1): 101-109.

[47] Rodriguez-Ortega, W. M., Martinez, V., Rivero, R. M., Camara-Zapata, J. M., Mestre, T., Garcia-Sanchez, F. (2017): Use of a smart irrigation system to study the effects of irrigation 
management on the agronomic and physiological responses of tomato plants grown under different temperatures regimes. - Agricultural Water Management 183: 158-168.

[48] Sarker, B. C., Hara, M., Uemura, M. (2005): Proline synthesis, physiological responses and biomass yield of eggplants during and after repetitive soil moisture stress. - Sci. Hortic. 103: 387-402.

[49] Sensoy, S., Ertek, A., Gedik, I., Kucukyumuk, C. (2007): Irrigation frequency and amount affect yield and quality of field-grown melon (Cucumis melo L.). - Agricultural Water Management 88: 269-274.

[50] Sezen, S. M., Yazar, A., Eker, S. (2006): Effect of drip irrigation regimes on yield and quality of field grown bell pepper. - Agricultural Water Management 81: 115-131.

[51] Sezen, S. M., Yazar, A., Daşgan, Y., Yücel, S., Akyıldız, A., Tekin, S., Akhoundnejad, Y. (2014): Evaluation of crop water stress index (CWSI) for red pepper with drip and furrow irrigation under varying irrigation regimes. - Agric. Water Manage. 143: 59-70.

[52] Sezen, S. M., Yazar, A., Tekin, S. (2019): Physiological response of red pepper to different irrigation regimes under drip irrigation in the Mediterranean region of Turkey. - Scientia Horticulturae 245: 280-288.

[53] Silber, A., Xu, G., Levkovitch, I., Soriano, S., Bilu, A., Wallach, R. (2003): High fertigation frequency: the effects on uptake of nutrients, water and plant growth. - Plant and soil 253: 467-477.

[54] Steel, R. G. D., Torrie, J. H. (1980): Principles and Procedures of Statistics. - 2nd ed. McGraw-Hill, New York.

[55] Ta, T. H., Shin, J. H., Noh, E. H., Son, J. E. (2012): Transpiration, growth, and water use efficiency of paprika plants (Capsicum annuum L.) as affected by irrigation frequency. Horticulture, Environment, and Biotechnology 53: 129-134.

[56] Weng, J. H., Chien, C. T., Chen, C. W., Lai, X. M. (2011): Effects of osmotic- and highlight stresses on PSII efficiency of attached and detached leaves of three tree species adapted to different water regimes. - Photosynthetica 49: 555-563.

[57] Yao, C., Moreshet, S., Aloni, B. (2001): Water relations and hydraulic control of stomatal behaviour in bell pepper plant in partial soil drying. - Plant Cell Environ. 24(2): 227-235.

[58] Yazar, A., Howell, A. T., Dusek, D. A., Copeland, K. S. (1999): Evaluation of crop water stress index for LEPA Irrigated Corn. - Irrig. Sci. 18: 171-180.

[59] Zhang, B., Liu, Y., Xu, D., Cai, J., Li, F. (2011): Evapotranspiration estimation based on scaling up from leaf stomatal conductance to canopy conductance. - Agricultural and Forest Meteorology 151: 1086-1095. 